\title{
Cenozoic and Mesozoic basalts from Egypt: a preliminary survey with a view to paleointensity
}

\author{
M. Perrin ${ }^{1}$, A. Saleh ${ }^{2}$, and L. Alva-Valdivia ${ }^{3}$ \\ ${ }^{1}$ Géosciences, UMR CNRS-UMII 5243, Université Montpellier II, France \\ ${ }^{2}$ National Research Institute of Astronomy and Geophysics, Helwan, Cairo, Egypt \\ ${ }^{3}$ Laboratorio de Paleomagnetismo y Geofisica Nuclear, Instituto de Geofisica, UNAM, Mexico
}

(Received December 22, 2007; Revised April 25, 2008; Accepted May 5, 2008; Online published January 23, 2009)

\begin{abstract}
Numerous phases of igneous activity took place in Egypt during the Mesozoic and the Cenozoic but no paleointensity results have ever been published from these rocks. Therefore a preliminary survey was conducted in the northern part of Egypt and in Sinai to test the suitability of these basalts for paleointensity determinations. Three Oligo-Miocene sites have been sampled north of Cairo: Abu Zaabal, Qatrani, and 6th of October City. In Sinai, we sampled Jurassic basalts in Wadi Budra and Oligo-Miocene rocks from Wadi Nukhul. The main magnetic carriers of these rocks are titanomagnetites with varying Ti content. Large secondary components are present in most middle Jurassic basalts and discrepancies remain in the directional analysis so this sill cannot be used for paleointensity experiments and the associated poles should not be considered for paleomagnetic reconstructions either. Directional analysis of the Oligo-Miocene basalts is very straightforward and updated mean VGPs have been calculated from the Cairo area $\left(68.9^{\circ} \mathrm{N}, 91.3^{\circ} \mathrm{E}\right.$; Kappa $\left.=274 ; A_{95}=3.7\right)$ and from Wadi Nukhul $\left(72.7^{\circ} \mathrm{N}, 13.4^{\circ} \mathrm{E}\right.$; Kappa $\left.=528 ; A_{95}=5.4\right)$. Pseudo-paleointensity results obtained as well from stable Egypt as from Sinai are promising, with values lower or similar (between 29 to $58 \mu \mathrm{T}$ ) to present-day field intensity.
\end{abstract}

Key words: Paleomagnetism, paleointensity, Oligo-Miocene, Jurassic, basalt, Egypt.

\section{Introduction}

A very good and detailed description of the Geology of Egypt has been published in English by Rushdi Said (1962, book updated in 1990), and a complete list of references for the original papers mainly in Arabic is given. Different phases of igneous activity took place in Egypt during its post Cambrian geological history. Chemical characteristics, size and mode of eruption of the Paleozoic and Mesozoic volcanic rocks are diversified whereas the Cenozoic volcanism is largely basaltic. Paleozoic volcanics are mainly found on the stable shelf that borders the AraboNubian massif, with early Paleozoic (pan-African; 500$550 \mathrm{Ma})$ and Permo-Triassic (220-250 Ma) ages. The Mesozoic volcanic rocks can generally be related to two main phases of igneous activity in the Late Jurassic-Early Cretaceous (125-155 Ma) and in the Late Cretaceous-Early Tertiary (60-90 Ma). They are located mainly in the Eastern and Western deserts and in Sinai. Several episodes of volcanic activity occurred during the Cenozoic, the earliest of Paleocene age being the continuation of the extensive late Cretaceous igneous activity. Mid Tertiary volcanism is widespread, with successive pulses in the Late Eocene followed by phases related to the opening of the Red Sea and ranging in age from Late Oligocene to Middle Miocene. This volcanism is uniformly basaltic and widely distributed

Copyright (c) The Society of Geomagnetism and Earth, Planetary and Space Sciences (SGEPSS); The Seismological Society of Japan; The Volcanological Society of Japan; The Geodetic Society of Japan; The Japanese Society for Planetary Sciences; TERRAPUB in the northern part of Egypt and in Sinai. The Quaternary volcanic activity took place mainly in the south Western desert.

However, very few paleomagnetic results are available for the period 0-200 Ma: a few tens of data in the last update of the global paleomagnetic database (GPMDB Version 4.6, compiled by Sergei A. Pisarevsky, The University of Western Australia, 2005). Also no paleointensity results have ever been published from these rocks. Furthermore the analysis of the directional data is not straightforward and ambiguities remain, as well for the Mesozoic than the Tertiary. For example, conflicting paleomagnetic results (Wassif, 1989; Ibrahim et al., 2000) were found for the Jurassic Wadi Budra basalt. Also Tertiary basalts in the areas around Cairo were supposed to define a reliable Early Miocene paleomagnetic pole for the African plate. But surprisingly, Lotfy (1992) and Lotfy et al. (1995) found two different groups of paleomagnetic directions. What has been long considered as one single Early Miocene magmatic episode would be in fact two different phases of volcanism? Finally, Tertiary pole positions defined for Sinai (Wassif, 1991; Abdeldayem and Tarling, 1996; Ibrahim et al., 1998; Saleh et $a l ., 2004)$ are in agreement neither with other Tertiary pole positions for Egypt, nor with South African poles. Let's note here that discrepancies also exist within Africa, between the South and West African cratons, especially in Mesozoic time. In order to avoid an unnecessary complication in our analysis, only results from South Africa (in the general) will be considered here. 
Therefore in order to better understand the relations between Sinai, Egypt and South Africa, a new sampling was planned. Considering the time needed for a paleointensity experiment and the usually low success rate (often less than $20 \%$ ), a preliminary survey has been conducted in the northern part of Egypt and in Sinai to redefine the paleodirections, and test the suitability of the basalts for paleointensity experiments.

\section{Geologic Setting and Sampling}

In Sinai, we concentrate on the Abu Zenima area (Fig. 1) and sampled two localities (4 sites, 38 samples): i) Middle Jurassic basalts in Wadi Budra, $\left[28.94^{\circ} \mathrm{N}, 33.30^{\circ} \mathrm{E}\right]$; and ii) Oligo-Miocene rocks from Wadi Nukhul, $\left[29.02^{\circ} \mathrm{N}\right.$, $33.16^{\circ} \mathrm{E}$ ]. Different areas have been visited north and west of Cairo and three Oligo-Miocene localities (49 samples) were sampled (Fig. 1): i) Abu Zaabal quarry $\left[30.28^{\circ} \mathrm{N}\right.$, $\left.31.35^{\circ} \mathrm{E}\right]$; ii) Qatrani quarry $\left[29.76^{\circ} \mathrm{N}, 30.70^{\circ} \mathrm{E}\right]$; and iii) 6 th of October City basalt, $\left[30.04^{\circ} \mathrm{N}, 30.99^{\circ} \mathrm{E}\right]$. All samples were drilled in the field using a gasoline-powered drill and oriented using both magnetic and sun compasses.

The Wadi Budra intrusion, west coast of Sinai, formed a basaltic sheet, 5 to $20 \mathrm{~m}$ thick, separating the underlying Ataqa Formation (Kostandi, 1959) of Carboniferous age, recently named Abu Thora Formation (Kora, 1995), from the overlying Budra Formation, also named Quiseb Formation, of Permo-Triassic age (Issawi and Jux, 1982) or Triassic age (Druckman et al., 1970; Beyth, 1981). Whole-rock $\mathrm{K}-\mathrm{Ar}$ determination (Mousa, 1987) gave a Middle Jurassic age of $182 \pm 7 \mathrm{Ma}$ for this basalt. This dating and the presence of a similar basaltic intrusion within the Carboniferous, $7.5 \mathrm{~km} \mathrm{SE}$ of the locality, indicate that this basaltic rock is a sill rather than a flow (Ibrahim et al., 2000). The Wadi Budra sill is not exposed continuously and five different outcrops have been sampled. Only a global tilt correction could be estimated from the sandstone-like country rock.

The Wadi Nukhul basalt is represented by a wide dyke intruding Eocene limestone that contains chert bands. This dyke lies about $8 \mathrm{~km} \mathrm{SW}$ of Abu Zenima, west coast of Sinai. It is nearly vertical and uniform in width $(\sim 10 \mathrm{~m})$. Close from the contact zone, limestone is baked and shows a black coloration. To the east, this dyke extends as a thin sill, conformable with sedimentary beds. Field observations suggest that the Wadi Nukhul intrusion is related to MidTertiary volcanism. A Miocene age was assigned by Ball (1916) and Hume et al. (1920) to this intrusion, while Andrew (1937) and Said (1962) referred it to the Oligocene. The Miocene age seems to be confirmed by one whole-rock $\mathrm{K}-\mathrm{Ar}$ determination at $22 \pm 1 \mathrm{Ma}$ (Steen, 1982). Two sites were sampled, one within the dyke and the other in the sill.

A large quarry is found at Abu Zaabal, northwest of Cairo, formed by a single sheet of basalt exceeding $60 \mathrm{~m}$ in thickness. The geology and petrology of this basaltic occurrence, together with several related basalt flows in the Cairo-Suez district, is given in a number of publications (e.g. Andrew, 1937; Said, 1962; El-Hinnawi and Abdel Maksoud, 1968). This basaltic flow overlies Oligocene sands and gravels, and is, in some place, usually unconformably overlain by marine Miocene sediments. The

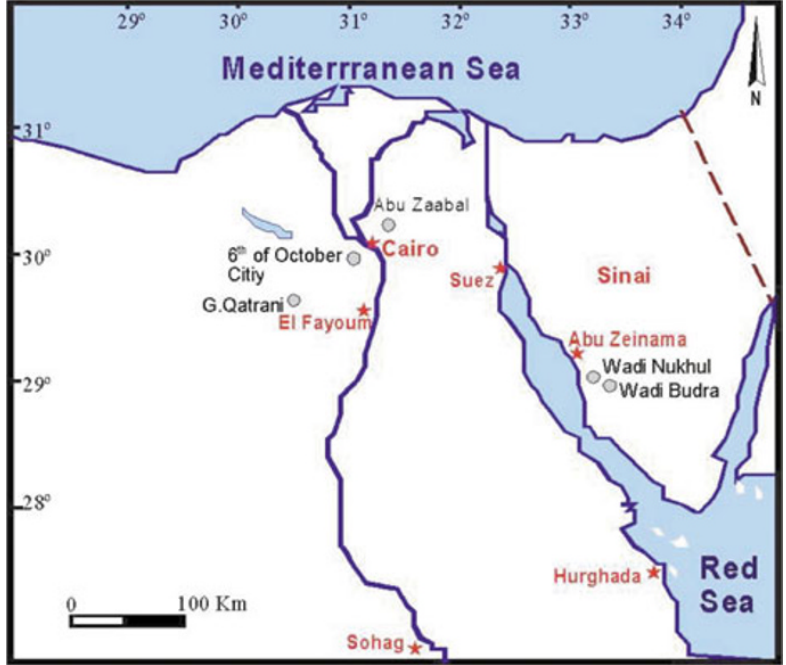

Fig. 1. Schematic map of the studied areas and location of the sampled sites (shaded circles).

stratigraphic and/or petrographic similarity of all CairoSuez basalts tends to indicate only one phase of magmatic activity, emplaced along the faults that affected the area during the Oligocene (Said, 1962). The doleritic basalt of Abu Zaabal yielded two whole rock K/Ar ages of 22 and $23 \mathrm{Ma}$ (Meneisy and Kreuzer, 1974). Two sites (27 samples) were sampled: site AZ2 was located about one kilometer to the west of site AZ1. The sheet of basalt is flat-lying, so no tilt correction was necessary. In site AZ1, the lowest exposed part of the flow was too weathered for sampling, so the cores were taken in the upper middle part of the flow; site AZ2 corresponds to the upper part of the flow, close from the top.

The area around 6th of October City, west of Cairo, is underlain by a succession of sedimentary rocks ranging in age from Upper Cretaceous to Quaternary. Basalt, found within the sedimentary sequence, is described as one sheet lying between the Oligocene and the Miocene sands and gravels. It is mineralogically and chemically indistinguishable from the basalt at Gebel Qatrani and Abu Zaabal but quite different from other basalts in Lower and Middle Egypt (Harrell and Bown, 1995). An outcrop found near the city was sampled (oriented bloc) to test the properties of the basalt.

The Qatrani area, North Western desert, is underlain by a succession of fluviomarine and continental sedimentary rocks ranging in age from Middle Eocene to Pleistocene (e.g. Beadnell, 1905; Said, 1962; El-Hinnawi, 1965; El Hinnawi and Abd El Maksoud, 1968, 1972; Abdel Monem and Heikal, 1981). The name "Gebel Qatrani" was given to a prominent scarp which forms the northwestern rim of the Fayum Depression. Northwest of that scarp, there is an extensive plateau covered by Miocene sands and gravels. Previous workers reported the occurrence of basalt within the sedimentary sequence as one sheet lying between the Oligocene Qatrani Formation and the Miocene sands and gravels, with thickness ranging from 20 to $100 \mathrm{~m}$. However, according to Heikal et al. (1983), Gebel Qatrani basalt formed a succession of three distinct sheets (A, B, and C sheets from bottom to top, respectively). Sheets $A$ and $C$ are 

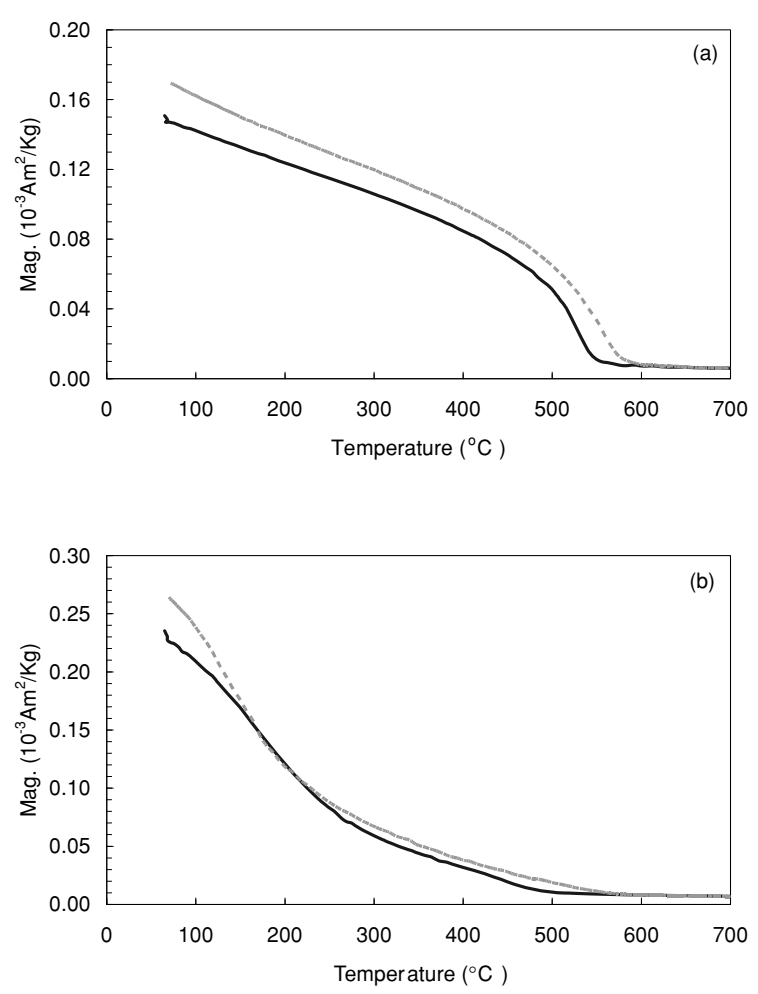

Fig. 2. Characteristic thermomagnetic curves:(a) Abu Zaabal and (b) Wadi Nukhul. Unbroken and dashed lines respectively for heating and cooling cycles.

characteristically amygdaloidal and vesicular, and mostly intensely altered. Sheet B, the most conspicuous sheet in the succession, is massive, fine grained, and mostly fresh, therefore the only one that can be paleomagnetically studied. It is 7 to $10 \mathrm{~m}$ thick, and continuous all along the basaltic outcrop, except in its southwestern 3. It forms a noticeable ledge at the top of the Qatrani scarp. The basalt of Gebel Qatrani yielded four whole-rock K-Ar ages ranging between 23 and $27 \mathrm{Ma}$ (Meneisy and Abdel Aal, 1984). Major and trace element studies indicate that the basalt of Qatrani is tholeiitic, formed in a rift environment. Two sites, about $10-15 \mathrm{~km}$ apart, were sampled within the flat-lying Qatrani basalt.

\section{Rock Magnetic Measurements}

A set of basic rock magnetic experiments was performed on at least one specimen from each site. These measurements included thermomagnetic curves and hysteresis loops using the variable field translation balance (VFTB) that measured in air, from the Geomagnetic Laboratory of Liverpool. Measurements of the magnetic remanence were conducted using a squid spinner magnetometer.

All samples are characterized by fairly reversible heating and cooling curves during thermomagnetic $\left(J_{\mathrm{s}}-T\right)$ cycles indicating titanomagnetite as the main carrier of magnetization in these rocks. Two types of curves have been observed: the first ones, as the example shown from Abu Zaabal (Fig. 2(a)), are characteristic of low Ti titanomagnetite with Curie temperatures between $500^{\circ} \mathrm{C}$ and $550^{\circ} \mathrm{C}$; the rest of the samples display curves characteristic of titanomagnetite richer in Titanium, with Curie points on the
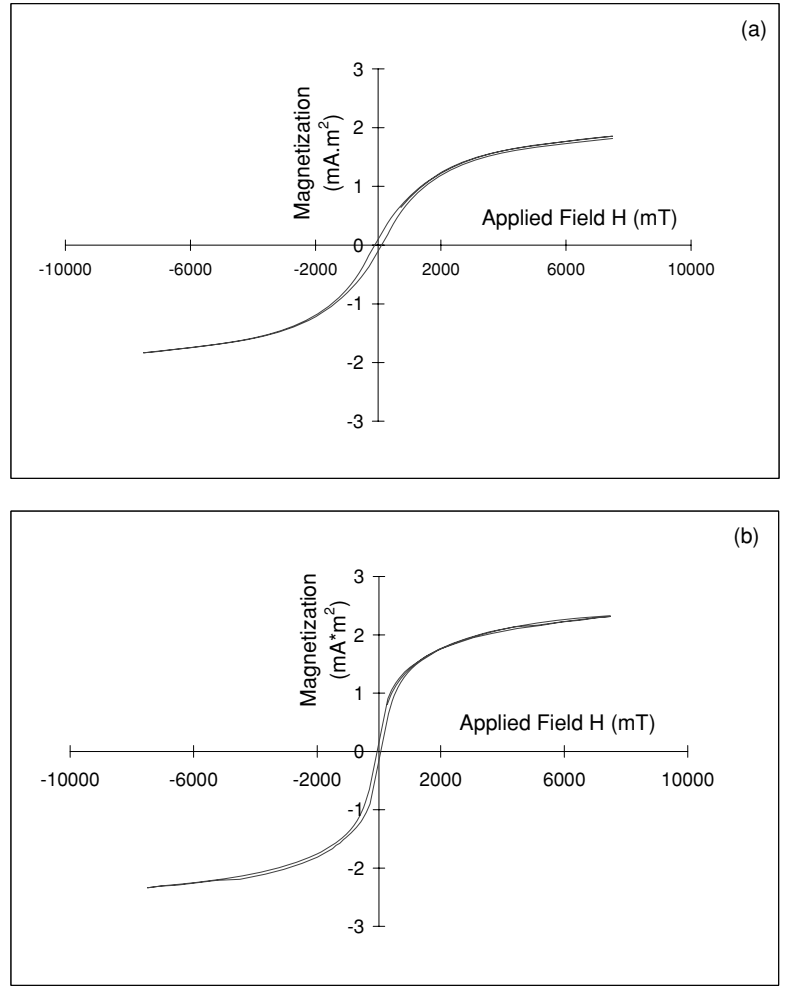

Fig. 3. Characteristic hysteresis loops: a) Abu Zaabal and b) Wadi Nukhul.

order of 300-400 ${ }^{\circ}$, as in Wadi Nukhul (Fig. 2(b)).

Typical examples of hysteresis loops of the basaltic rock samples are shown in Fig. 3. The hysteresis parameters $B_{\mathrm{cr}} / B_{\mathrm{c}}$ versus $M_{\mathrm{rs}} / M_{\mathrm{s}}$ (Fig. 4) cluster within the pseudo single domain (PSD) grain size range on a Day plot (Day et al., 1977). Microscopic investigation under reflecting light, performed on one sample from each site, shows the presence of large magnetite with ilmenite-magnetite intergrowth, indicating a high temperature oxidation of ilmenite lamellae in titanomagnetite (Fig. 5).

\section{Paleomagnetic Analysis}

All samples were cut into specimens at the University of Montpellier. Few differences were found between readings from magnetic and sun compasses, apart from the mean 2004 magnetic declination which was around $3^{\circ} \mathrm{E}$. One half specimen from each core was then stepwise demagnetized using alternating fields (AF) up to $170 \mathrm{mT}$ with the automated degauss system coupled with a 760 Superconducting rock Magnetometer SRM manufactured by $2 \mathrm{G}$ enterprises of the Montpellier paleomagnetic laboratory. Mean Characteristic Remanent Magnetizations (ChRM) were calculated by principal component analysis (Kirschvink, 1980), with the upper limit for the Maximum Angular Deviation (MAD) chosen as 5.

\subsection{Middle Jurassic basalts}

During AF demagnetization, two different components of magnetization were present. The low coercivity components are removed by applying fields between 5 and $20 \mathrm{mT}$, depending on the samples. The dispersion of the directions associated with these low-field components is very large, almost random. This fact added to a very low Median De- 




Fig. 4. Day plot for the Egyptian samples.

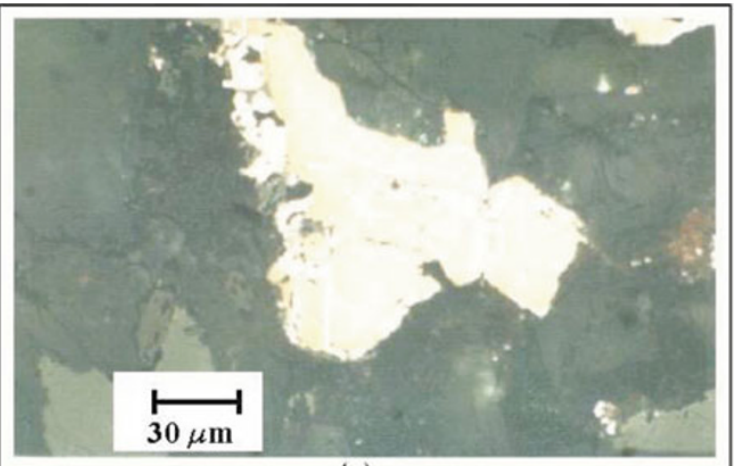

(a)



Fig. 5. Photo Micrographs in reflected light: (a) Qatrani basalt and (b) Abu Zaabal basalt.

structive Field (half of the Natural Remanent Magnetization NRM is removed by $5-10 \mathrm{mT}$ ) points to an isothermal process for the acquisition of these secondary components, likely during lightning strikes. However, at higher fields, characteristic directions of magnetization can be isolated, usually between 20 and $70 \mathrm{mT}$. These directions are well defined (Table 1; Fig. 6) with MAD between 0.7 and 4.3 and a good grouping at the site level (kappa $\left.=157 ; \alpha_{95}=3^{\circ}\right)$.
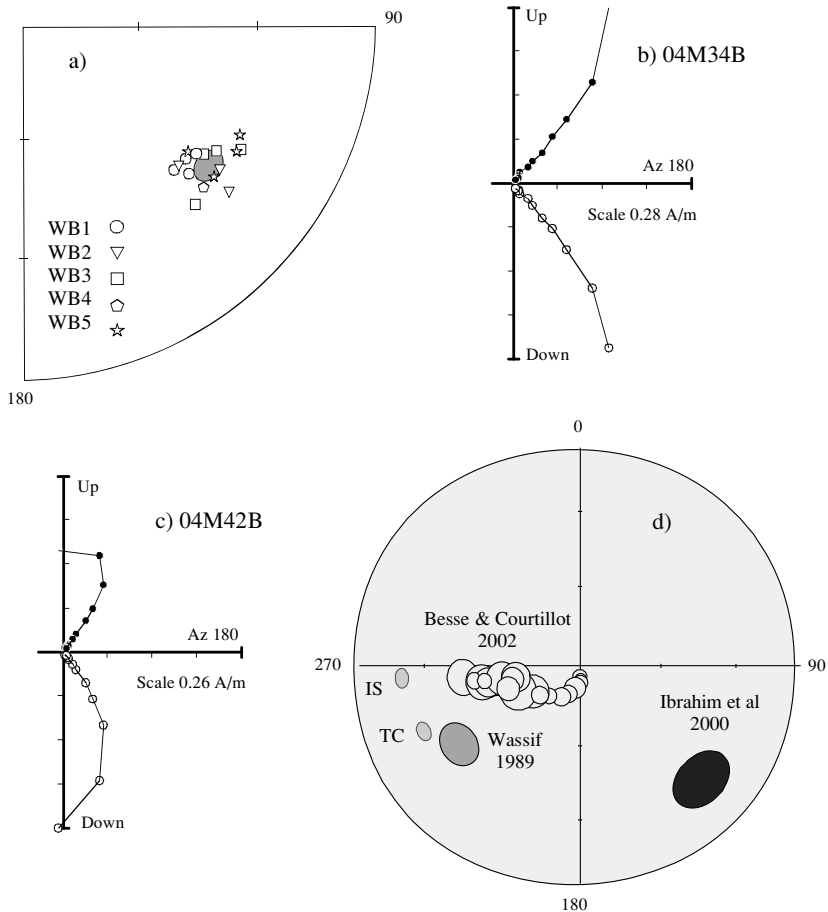

Fig. 6. Paleomagnetic analysis of the middle Jurassic basalts: (a) equal-area plot with individual ChRM directions and $\alpha_{95}$ confidence circle of the mean site direction; (b) and (c) orthogonal diagrams with open/close circles for horizontal/vertical projections respectively; and (d) polar equal-area projection for Jurassic VGPs. IS and TC are respectively our in situ and tilt corrected mean directions. (Besse and Courtillot, 2002): South Africa synthetic apparent polar wander path for the past $200 \mathrm{Ma}$ calculated for a $10 \mathrm{Ma}$ sliding window every $5 \mathrm{Ma}$.

This new study was expected to decide in favor of one of the two conflicting paleomagnetic results (Wassif, 1989; Ibrahim et al., 2000) obtained for the Wadi Budra basalt. However, as can be seen from Table 1 and Fig. 6(d), there are amazingly large differences between the three sets of Virtual Geomagnetic Poles (VGP). Wassif's VGP is much closer to our results but still differ by an angle of respectively 14 and $30^{\circ}$, depending on the reference frame we used for our data (tilt corrected TC or in situ IS). The angular difference becomes very large when comparing Ibrahim et al.'s result to our TC and IS data (respectively 100 and $116^{\circ}$ ). Furthermore all three poles are significantly different from the Master Polar Wander Path (Besse and Courtillot, 2002) for South Africa as also shown in Fig. 6(d). Ibrahim et al. (2000) considered different parameters to try to explain the discrepancy between their data and Wassif's results. Among them, they mentioned local tectonic movements, global tectonics and secular variation. It is obvious that even though secular variation is clearly not averaged out in such a sill, it cannot account for differences on the order of $100^{\circ}$. It is exactly the same for global tectonic movements between South Africa, Egypt and the Sinai Peninsula which could account for a few tens of degrees but unlikely for that kind of angles. In this new analysis, we tried to estimate the influence of local tectonics in the discrepancy. As said before, the Wadi Budra sill is not exposed continuously and therefore bloc rotation from one outcrop to the other could explain dispersion of the directions. However, 
Table 1. Published paleomagnetic data from Wadi Budra, West coast of Sinai (Middle Jurassic; $182 \pm 7$ Ma). $N / N_{0}$ : Number of samples used in the calculation/Total number of samples.

\begin{tabular}{|c|c|c|c|c|c|c|c|c|c|}
\hline \multicolumn{2}{|c|}{ Site } & \multirow{2}{*}{$N / N_{0}$} & \multicolumn{4}{|c|}{ Direction } & \multicolumn{2}{|c|}{ VGP } & \multirow{2}{*}{ Reference } \\
\hline Lat ${ }^{\circ} \mathrm{N}$ & Long ${ }^{\circ} \mathrm{E}$ & & Dec & Inc & $k$ & $\alpha_{95}$ & Lat & Long & \\
\hline $28^{\circ} 55^{\prime}$ & $33^{\circ} 20^{\prime}$ & 29 & 63.3 & 8.0 & & $10.2^{\circ}$ & $25^{\circ} \mathrm{N}$ & $133^{\circ} \mathrm{E}$ & Ibrahim et al. (2000) \\
\hline $28^{\circ} 57^{\prime}$ & $33^{\circ} 19^{\prime}$ & 4 & 159.0 & 39.6 & 150 & $7.5^{\circ}$ & $35^{\circ} \mathrm{N}$ & $237^{\circ} \mathrm{E}$ & Wassif (1989) \\
\hline $28^{\circ} 56^{\prime}$ & $33^{\circ} 18^{\prime}$ & $16 / 19$ & 127.5 & 35.9 & 157 & $3.0^{\circ}$ & $20^{\circ} \mathrm{N}$ & $266^{\circ} \mathrm{E}$ & This study-In situ \\
\hline $28^{\circ} 56^{\prime}$ & $33^{\circ} 18^{\prime}$ & $16 / 19$ & 145 & 47 & 157 & $3.0^{\circ}$ & $24^{\circ} \mathrm{N}$ & $247^{\circ} \mathrm{E}$ & This study-Tilt corrected \\
\hline
\end{tabular}

Table 2. Comparison of previously published paleomagnetic data with the Oligo-Miocene data derived from the present study $B$ : number of sites; $N / N_{0}$ : Number of samples used in the calculation/Total number of samples; *for recalculated VGPs. Symbols used in Fig. 10 and explained in text. In italic, not used for mean calculation.

\begin{tabular}{|c|c|c|c|c|c|c|c|c|c|c|c|c|c|c|}
\hline \multirow{2}{*}{ Area } & \multirow{2}{*}{ Site } & \multirow{2}{*}{ Age } & \multicolumn{5}{|c|}{ Site } & \multicolumn{4}{|c|}{ In situ } & \multicolumn{2}{|c|}{ VGP } & \multirow{2}{*}{ Reference } \\
\hline & & & Symbol & Lat ${ }^{\circ} \mathrm{N}$ & Long ${ }^{\circ} \mathrm{E}$ & $B$ & $N / N_{0}$ & Dec & Inc & $k$ & $\alpha_{95}$ & Lat & Long & \\
\hline \multirow{2}{*}{$\begin{array}{c}\text { Northeast } \\
\text { Cairo }\end{array}$} & \multirow{2}{*}{ Abu Zabel } & \multirow{2}{*}{$22-23 \mathrm{Ma}$} & azp & $30.28^{\circ}$ & $31.36^{\circ}$ & 2 & $26 / 27$ & 200.3 & -60 & 673 & $1.1^{\circ}$ & $70^{\circ} \mathrm{N}$ & $83^{\circ} \mathrm{E}$ & This study \\
\hline & & & azl & $30.18^{\circ}$ & $31.11^{\circ}$ & 4 & 132 & 202 & -58 & & $8^{\circ}$ & $70 N^{*}$ & $90 \mathrm{E}^{*}$ & Lofty (1992) \\
\hline \multirow{4}{*}{$\begin{array}{c}\text { Southwest } \\
\text { Cairo }\end{array}$} & \multirow{4}{*}{ Qatrani } & \multirow{4}{*}{ 23-27 Ma } & $\mathrm{qp}$ & $29.71^{\circ}$ & $30.65^{\circ}$ & 2 & $17 / 21$ & 207.3 & -58.5 & 249 & $2.3^{\circ}$ & $66^{\circ} \mathrm{N}$ & $90^{\circ} \mathrm{E}$ & This study \\
\hline & & & ql & $29.42^{\circ}$ & $30.40^{\circ}$ & 11 & & 203 & -59 & & $7^{\circ}$ & $68^{\circ} \mathrm{N}$ & $87^{\circ} \mathrm{E}$ & Lofty (1992) \\
\hline & & & qa & 29.6 & 30.6 & 2 & 15 & 207 & -55 & 271 & - & 67 & 98 & Abdeldayem (1999) \\
\hline & & & qh & 29.67 & 30.50 & & 15 & 209.2 & -60.2 & 472 & 1.0 & 64 & 87 & Hussain et al. (1980) \\
\hline \multirow{2}{*}{$\begin{array}{l}\text { North } \\
\text { Cairo }\end{array}$} & \multirow{2}{*}{$\begin{array}{l}\text { East } \\
\text { West }\end{array}$} & \multirow{2}{*}{ Early Miocene } & ecl & $30.08^{\circ}$ & $31.52^{\circ}$ & 11 & 132 & 198 & -24 & 417 & 3 & 66 & $164 *$ & \multirow{2}{*}{ Lofty et al. (1995) } \\
\hline & & & wcl & $30^{\circ}$ & $31^{\circ}$ & 18 & 216 & 197 & -51 & 270 & 3 & 76 & 111 & \\
\hline \multirow{3}{*}{$\begin{array}{c}\text { West coast } \\
\text { of Sinai }\end{array}$} & \multirow{3}{*}{ Wadi Nukhul } & \multirow{3}{*}{$22 \pm 1 \mathrm{Ma}$} & wnp & $29.02^{\circ}$ & $33.16^{\circ}$ & & $10 / 18$ & 168.7 & -63.6 & 76 & $5.6^{\circ}$ & $71^{\circ} \mathrm{N}$ & $7^{\circ} \mathrm{E}$ & This study \\
\hline & & & wnw & $29^{\circ} 00^{\prime}$ & $33^{\circ} 15^{\prime}$ & & & 173.5 & -60.7 & 47 & $8.2^{\circ}$ & $76^{\circ} \mathrm{N}$ & $13^{\circ} \mathrm{E}$ & Wassif (1991) \\
\hline & & & wns & $29.02^{\circ}$ & $33.16^{\circ}$ & & 47 & 174 & -65 & 103 & $12^{\circ}$ & $71^{\circ} \mathrm{N}$ & $20^{\circ} \mathrm{E}$ & Saleh et al. (2004) \\
\hline
\end{tabular}
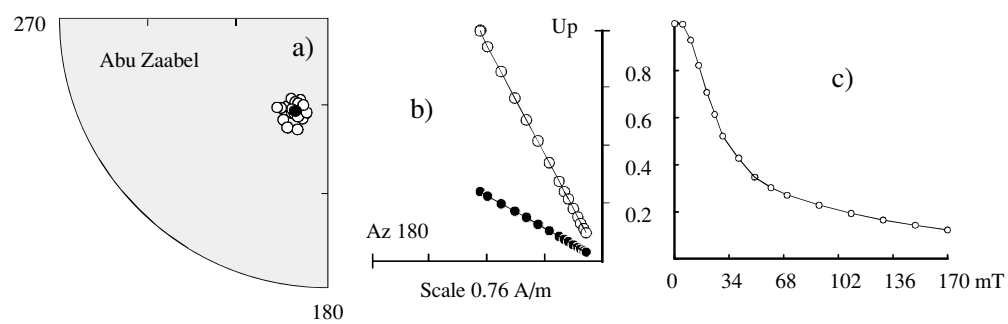

Fig. 7. Paleomagnetic analysis of Oligo-Miocene basalts from Abu Zaabal: (a) equal-area plot with ChRM directions and mean $\alpha_{95}$ confidence circle; (b) orthogonal diagram; and (c) demagnetization curve.

no significant differences could be found between results obtained from the five different outcrops (WB1 to WB5) we sampled as can be seen from Fig. 6(a). New analysis is still needed to try to solve the Wadi Budra ambiguity and, for the moment, these poles cannot be used for paleomagnetic reconstructions, or for paleointensity experiments.

\subsection{Oligo-Miocene basalts}

The magnetic behavior of all samples from the 22-23 Ma Abu Zaabal quarry, north of Cairo, is very simple, with only one component of magnetization likely of primary origin (Fig. 7(b)). Despites the fact that both sites sampled different parts of the flow, the magnetic properties of the samples are very similar (NRM intensities, coercivities, and thermomagnetic behavior). About $20 \%$ of the magnetization being left after demagnetization at $170 \mathrm{mT}$, hematite is likely a carrier of magnetization. All best fits have been estimated between room temperature and $170 \mathrm{mT}$ with MAD between 0.3 and 0.6. ChRM directions are identical for both sites, with an Abu Zaabal mean direction \{azp\} extremely well defined $\left(\alpha_{95}=1.1\right.$; kappa $=673$; see Table 2 and Fig. $\left.7(\mathrm{a})\right)$.

The magnetization of the samples from the flat-lying $23-$
$27 \mathrm{Ma}$ Qatrani basalt, west of Cairo, is also mainly univectorial (MAD between 0.4 and 1.6), apart from a soft viscous component removed by 5-10 mT (Fig. 8(b)). However the magnetic properties of samples from both sites are fairly different. All samples from Q2, as well as one sample from Q1, have low coercivities (e.g. Fig. 8(d) and (e)) while all other samples from Q1 are much harder with about $20 \%$ of the magnetization left after $170 \mathrm{mT}$ (e.g. Fig. 8(b) and (c)). Anyway, there is no systematic directional difference between both sites (Fig. 8(a)) and the mean site direction $\{q p\}$ is well defined $\left(\alpha_{95}=2.3\right.$; kappa $=249$; see Table 2 and Fig. 8(a)).

Unfortunately the analysis of the lower Miocene Wadi Nukhul samples, southwestern coast of Sinai, is not so straightforward. Secondary components of magnetization are present in most samples up to $10-30 \mathrm{mT}$, with very scattered directions. For reasons already given for Wadi $\mathrm{Bu}-$ dra, these components are likely related to lightning strikes. After removal of the secondary components, ChRMs can be isolated for the majority of the samples (MAD between 0.3 and 1.9). Most samples have a magnetic behavior sim- 



Fig. 8. Paleomagnetic analysis of Oligo-Miocene basalts from Qatrani: (a) equal-area plot with ChRM directions and mean $\alpha_{95}$ confidence circle; (b)-(c) and (d)-(e) orthogonal diagram and demagnetization curve for Q1 and Q2 type samples respectively.

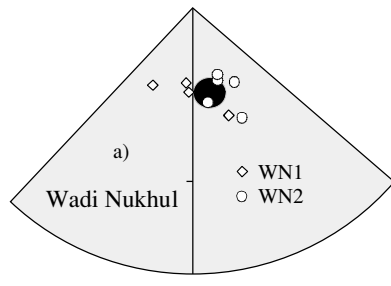

180

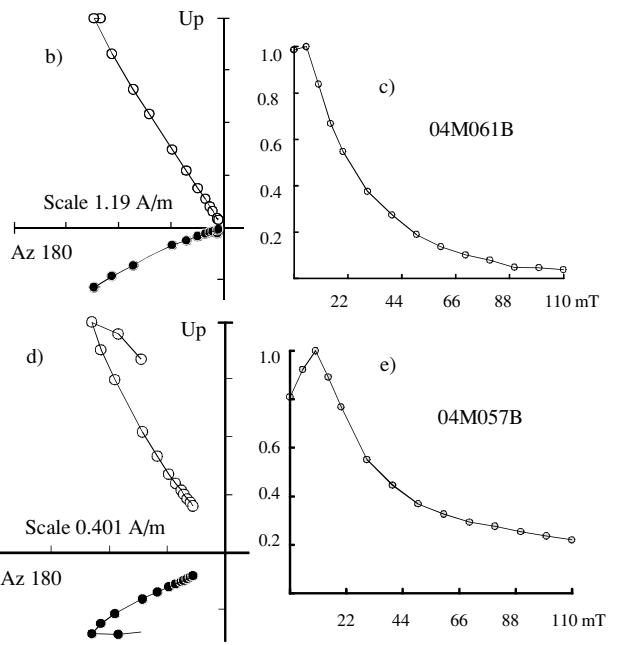

Fig. 9. Paleomagnetic analysis of Oligo-Miocene basalts from Wadi Nukhul: (a) equal-area plot with ChRM directions and mean $\alpha_{95}$ confidence circle; (b)-(c) and (d)-(e) orthogonal diagram and demagnetization curve for the two types of samples.

ilar to 04M61B (Fig. 9(b) and (c)), with a few looking like 04M057B (Fig. 9(d) and (e)). The ChRM directions are much more scattered with a significant difference between WN1 and WN2 (Fig. 9(a)). Slight differential rotations within the dyke could explain the difference, but no evidence was noticed in the field. More likely the difference is related to a slightly different timing in the acquisition of the magnetization and recording of secular variation. The mean site direction $\{w n p\}\left(\alpha_{95}=5.6\right.$; $\left.\mathrm{kappa}=76\right)$ is given in Table 2.

Oligo-Miocene virtual geomagnetic poles are shown in Fig. 10, together with results previously obtained from the same areas. Results obtained in this study from the Cairo area (Abu Zaabel $\{$ azp $\}$ and Qatrani $\{q p\})$ are in excellent agreement with most previously published results (Lofty, $1992\{$ azl $\}$ and $\{\mathrm{ql}\}$; Abdeldayem, 1999 qqa\}; Hussain et al., $1980\{\mathrm{qh}\}$; Table 2). However, about ten years ago, Lofty proposed the existence of two distinctive nonoverlapping components in the Oligo-Miocene volcanism north of Cairo (Lofty et al., 1995; Components $\{\mathrm{ecl}\}$ and $\{w c l\}$, Table 2$)$. No directions close to their $\{$ ecl $\}$ component has been found in this study, while their $\{\mathrm{wcl}\}$ component is comparable to all other directions. It is worth noting that, while the sites giving a $\{\mathrm{wcl}\}$ direction covered a

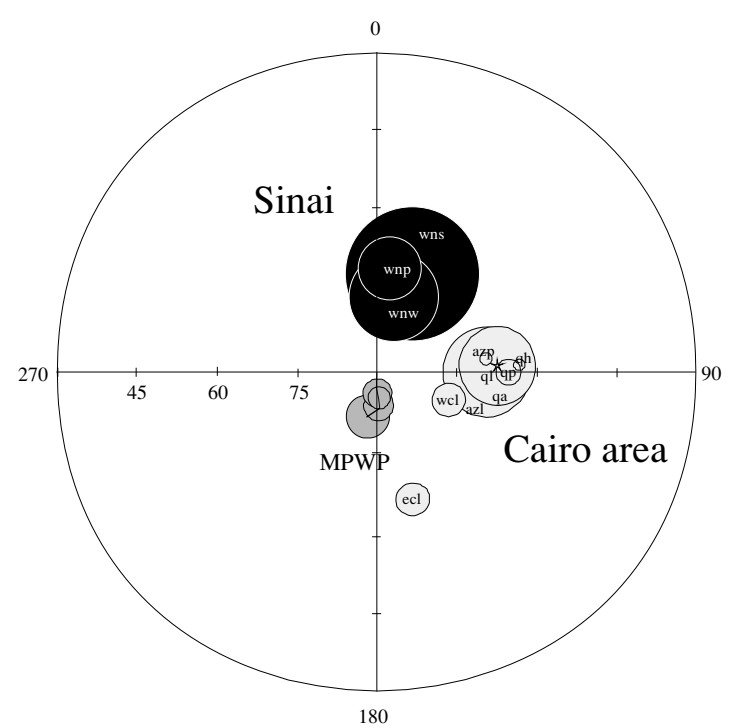

Fig. 10. Truncated $\left(30-90^{\circ}\right)$ polar equal-area projection for Oligo-Miocene VGPs. Symbols as in Table 2. MPWP is the Master Polar Wander Path for South Africa corresponding to the past $40 \mathrm{Ma}$ calculated for a $10 \mathrm{Ma}$ sliding window every $5 \mathrm{Ma}$ (Besse and Courtillot, 2002). 
fairly large geographic extent, all sites giving the $\{\mathrm{ecl}\} \mathrm{di}-$ rection come from the same volcanic body. Local tilt can then not be excluded to explain the $27^{\circ}$ difference (only in inclination, see Table 2) between their two directions. Excluding Lofty's $\{$ ecl $\}$ component, a mean Oligo-Miocene (22-27 Ma) VGP was calculated $\left(N=7\right.$; Lat $=68.9^{\circ} \mathrm{N}$; Long $=91.3^{\circ} \mathrm{E} ;$ Kappa $=274 ; A_{95}=3.7$ ) for the Cairo area. As all results are coming from volcanic rocks, one may wonder about secular variation. The geographic extent of the sampling (hundreds of $\mathrm{km}^{2}$ ) and the age difference between both units (22-23 Ma and 23-27 Ma respectively) are arguments against an instant recording of the magnetization throughout the sampling area. Paleosecular variation was estimated as the angular standard deviation (ASD = $11.0^{\circ}$ with $95 \%$ confidence limit $+5.2^{\circ} /-2.7^{\circ}$ ) of the VGPs (McFadden et al., 1991). This value is slightly lower than the value $\left(\sim 17^{\circ}\right)$ predicted by the PSV model of McFadden et al. (1991) for the time period and the paleolatitude, suggesting that secular variation has not been completely averaged out from this pole position.

Along the west coast of Sinai, besides our results $\{w n p\}$, two other analyses have been carried out on the Wadi Nukhul dyke (Wassif, $1991\{w n w\} ;$ Saleh et al., 2004 $\{$ wns $\}$ ). Even though all three analyses have $\alpha_{95}$ larger than for the Cairo area (see Fig. 10), the overlapping of the $A_{95}$ confidence circles is very good and an updated mean Wadi Nukhul VGP can be proposed $\left(N=3\right.$, Lat $=72.7^{\circ} \mathrm{N}$, Long $\left.=13.4^{\circ} \mathrm{E}, \mathrm{Kappa}=528, A_{95}=5.4\right)$.

The mean Oligo-Miocene VGP for the Cairo area is $24^{\circ}$ apart from the Wadi Nukhul pole, and both are respectively 23 and $24^{\circ}$ apart from the 20-30 Ma Master Poles for South Africa (Besse and Courtillot, 2002). Even though secular variation is probably not completely averaged out from these poles, it can unlikely account alone for that kind of differences and the tectonic relations between Sinai, stable Egypt and South Africa will have to be closer investigated with a more extensive paleomagnetic sampling.

\section{Pseudo-Thellier Experiments}

The primary goal of this analysis was to test the suitability of the Egyptian basalts for paleointensity experiments. Secondary components present in all Jurassic samples were too large for paleointensity purpose, but most Oligo-Miocene basalts were tested. Pseudo-Thellier (Perrin, 1998) and Thellier/Coe (Thellier and Thellier, 1959; Coe, 1967) experiments have been carried out with a controlled atmosphere vibrating thermo-magnetometer (Cat VTM; see Poidras et al., this issue), on all samples carrying only one component of magnetization (apart from a small viscous component).

The Cat VTM allows continuous measurement of both remanent and induced magnetizations by translating the sample (up to $12 \mathrm{~mm}$ in length and up to $10 \mathrm{~mm}$ in diameter) between two identical detection coils connected in opposition in order to cancel ambient field fluctuations, in an Argon atmosphere. The magnetic moment is measured with a precision of $2 \times 10^{-9} \mathrm{~A} \mathrm{~m}^{2}$. Two $\mu$ metal screens surround the entire device in order to cancel most of the ambient field at the center of the magnetometer, the remaining residual field in the measurement zone being dynamically compensated to zero. Samples can be subjected to automatic heating-cooling cycles from room temperature up to $700^{\circ} \mathrm{C}$ throughout the whole experiment, applying or not a field between 0 and $150 \mu \mathrm{T}$.

In the Pseudo-Thellier experiments (Perrin, 1998), samples are subjected to heating-cooling cycles, using the Cat VTM. Heatings are performed in zero field, and coolings with an applied field along the measurement axis. Let's start (Fig. 11) with the natural remanent magnetization of the sample $\left(\mathrm{NRM}_{\mathrm{RT}-T_{\mathrm{c}}}\right)_{\mathrm{RT}}$ (RT: room temperature, $T_{\mathrm{c}}$ : Curie point). After heating in zero field up to $100^{\circ} \mathrm{C}$, the remaining NRM is carried by grains having unblocking temperatures above $100^{\circ} \mathrm{C}$, which is $\mathrm{NRM}_{100-T_{\mathrm{c}}}$ measured at $100^{\circ} \mathrm{C}\left(\mathrm{NRM}_{100-T_{\mathrm{c}}}\right)_{100}$. The field is switched on and the sample is cooled to room temperature, thus acquiring a pTRM $\left(\mathrm{TRM}_{100-\mathrm{RT}}\right)$. The field is switched off, and $\mathrm{NRM}_{100-T_{\mathrm{c}}}$ is estimated again, but this time at room temperature, $\left(\mathrm{NRM}_{100-T_{\mathrm{c}}}\right)_{\mathrm{RT}}$ plus $\mathrm{TRM}_{100-\mathrm{RT}}$. The difference between this measurement and the previous one correspond to $\mathrm{TRM}_{100-\mathrm{RT}}$, assuming that $\mathrm{NRM}_{100-T_{\mathrm{c}}}$ is the same when measured at $100^{\circ} \mathrm{C}$ than at room temperature. The above assumption is of course not correct because of the reversible variation of $J_{\mathrm{S}}$ with temperature, and for natural rocks, $\left[\mathrm{NRM}_{100-T_{\mathrm{c}}}\right]_{T}$ will usually be lower than $\left[\mathrm{NRM}_{100-T_{\mathrm{c}}}\right]_{\mathrm{RT}}$ by a ratio that is equal to $J_{\mathrm{S}} / J_{\mathrm{S} 0}$, the effect being larger closer to the Curie point (Figs. 12(a2)-(a4), (b2)-(b4)). If the small specimen used for VTM measurements are drilled along the characteristic NRM direction, which was the case in our experiments, then $\mathrm{NRM}_{100-T_{\mathrm{c}}}$ and $\mathrm{TRM}_{100-\mathrm{RT}}$ can be used to construct the NRM-TRM diagram, and another cycle can be done at higher temperature.

To further assess the soundness of the pseudo-Thellier procedure as a selection tool, most tested samples were in addition submitted to Thellier/Coe experiments, also using the Cat VTM. In this case, an additional cycle is added to the process. After heating the sample to a given temperature, we first cool the sample in a zero field and measure the remnant NRM at room temperature before heating again to the same temperature and cooling with an applied field to acquire the pTRM. Additional cycles were also performed for pTRM checks at 200,300 , and $400^{\circ} \mathrm{C}$. A $50 \mu \mathrm{T}$ laboratory field was used as well for pseudoThellier as for Thellier/Coe experiments.

Both techniques are in excellent agreement as well in the favorable cases showing only one slope (Fig. 12(a)) as in the more complicated two slopes cases (Fig. 12(b)), and the paleointensity estimates are very close, except for the low temperature component of the two slope case where a much higher field is estimated from Thellier/Coe than from pseudo-Thellier experiments. So the pseudo-Thellier procedure, which is at least twice as fast as the Cat VTM Thellier/Coe experiments, is perfectly well suited as a selection criterion. However, as long as the Cat VTM will measure the magnetization only along one axis, none of them can replace conventional Thellier experiments satisfactorily. Also experimental errors can be expected to be slightly larger with the Cat VTM techniques as the samples have to be drilled along the direction of the characteristic magnetization (error usually less than $5^{\circ}$ ).

Even though the linearity of the pseudo-paleointensity re- 

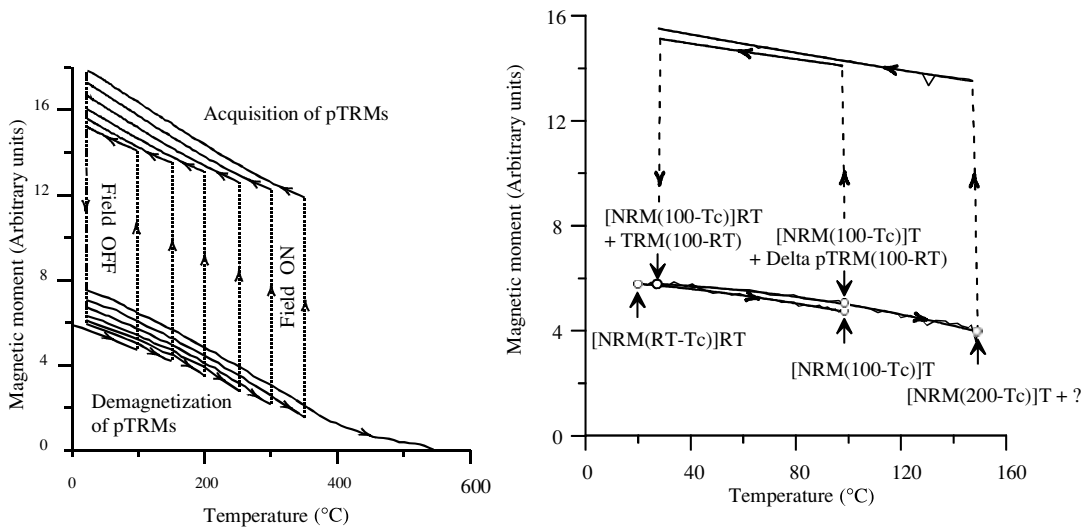

Fig. 11. Pseudo-Thellier procedure (reprint from Perrin, 1998). See text for details.
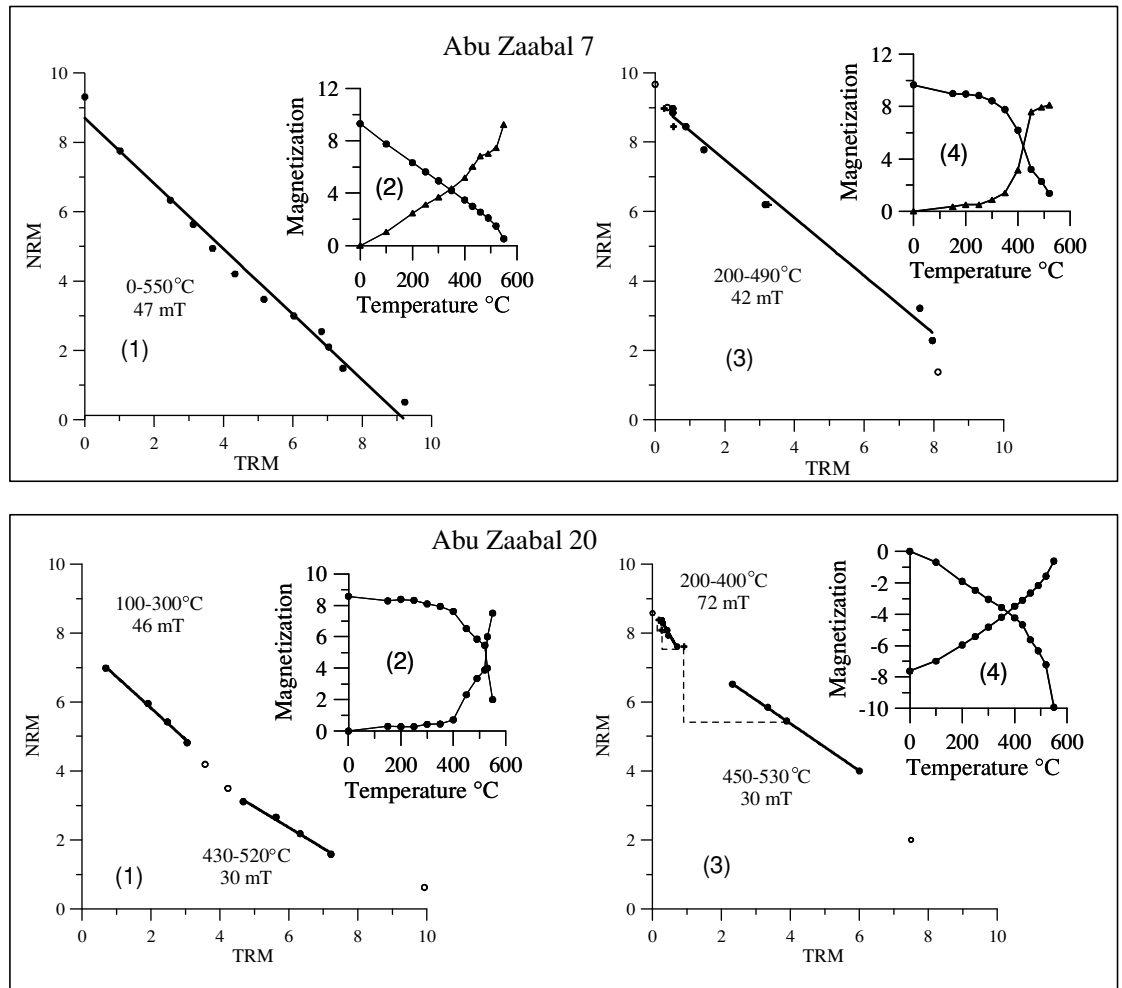

Fig. 12. Comparison of Pseudo-Thellier (PTE) and Thellier/Coe (TCE) paleointensity experiments, obtained from Abu Zaabal samples 7 (upper group of plots) and 20 (lower group of plots). Plots 1 and 3 are respectively NRM-TRM plots for PTE and TCE. Plots 2 and 4 are respectively demagnetization/remagnetization curves for PTE and TCE.

sults obtained from the Cairo area is not perfect (Figs. 12 and 13), about half of the samples gave very coherent values (between 34 and $58 \mu \mathrm{T}$ ), similar or slightly lower than the present-day $50 \mu \mathrm{T}$ dipole field. A few Sinai samples gave also acceptable results (Fig. 13) with even lower estimates (between 29 and $37 \mu \mathrm{T}$ ). Because of their simple directional analysis, their favorable magnetic properties and the consistency of their Pseudo-Thellier estimates, we think that these Oligo-Miocene basalts from Egypt are good candidates for an extensive paleointensity analysis.

\section{Conclusion}

After removal of secondary components, likely related to lightning strikes, paleomagnetic analysis of the middle Jurassic (182 $\pm 7 \mathrm{Ma}$ ) Wadi Budra basalts is easy, with well defined characteristic directions of magnetization and a good grouping at the site level $\left(\alpha_{95}=3.0^{\circ}\right)$. However, there is an amazingly large difference with a previously published result (Ibrahim et al., 2000), and a noteworthy difference with another pole (Wassif, 1989) also obtained from Wadi Budra sill. Furthermore all poles are significantly apart from the Master Apparent Polar Wander Path (Besse and Courtillot, 2002) for South Africa. Tectonic movements between South Africa, Egypt and the Sinai Peninsula could account for a few tens of degrees but unlikely for angles on the order of $30-116^{\circ}$. An extensive sampling as well on the stable part of Egypt as in Sinai will be needed to understand this discrepancy. In the meantime, none of the Wadi Budra poles should be used for paleomagnetic reconstruction. About paleointensity, the secondary components present in 



Fig. 13. NRM-TRM plots of Pseudo-Thellier paleointensity experiments for the other sites.

all samples are too large, and no further test was attempted. Other Jurassic localities will have to be tested.

The directional analysis of Oligo-Miocene basalts is very straightforward and updated mean VGPs have been calculated from the Cairo area $\left(N=7\right.$; Lat $=68.9^{\circ} \mathrm{N}$; Long $=$ $91.3^{\circ} \mathrm{E}$; Kappa $\left.=274 ; A_{95}=3.7\right)$ and for Sinai $(N=3$; Lat $=72.7^{\circ} \mathrm{N}$; Long $=13.4^{\circ} \mathrm{E}$; Kappa $\left.=528 ; A_{95}=5.4\right)$. A $24^{\circ}$ angular difference exists between the Cairo and the Wadi Nukhul mean VGPs, and both are respectively 23 and 24a apart from the 20-30 Ma Master Poles for South Africa (Besse and Courtillot, 2002). Secular variation can unlikely account alone for that kind of differences and a more extensive paleomagnetic sampling will be needed to better constrain movements between South Africa, Egypt and the Sinai Peninsula during the Oligo-Miocene.

Considering the time needed for a classic paleointensity experiment, the lack of physical grounds for most natural samples (PSD grains) and therefore the high failure rate (often up to $80 \%$ ), selection of sample favorable for that type of analysis has always been a goal in the community. Bulk rock magnetic parameters often failed to successfully select samples as they not necessarily describe the magnetic properties of the phase carrying the NRM. The pseudo-Thellier experiments used here mimic true Thellier experiments but, as they are fully automated, they are much faster and much easier to use for selection of the reliable samples. However, they cannot replace true Thellier experiments.

Even though the technical quality of the pseudopaleointensity results obtained as well from the North Cairo area as from Sinai is not perfect, the consistency of the results is promising, with values between 35 to $58 \mu \mathrm{T}$ for the Cairo area and between 29-37 $\mu \mathrm{T}$ for Sinai. Therefore this preliminary survey emphasizes clearly the need of a detailed sampling of Jurassic and Cenozoic basalts from Egypt, as well for directional as paleointensity purposes. Considering both directional results and pseudo-Thellier, results should be obtained first from the Oligo-Miocene of stable Egypt.

Acknowledgments. This work was supported by NRIAG and by CNRS (Contribution CNRS-INSU-DyETI). The authors are grateful to thank Manuel Calvo and Mads Furschou Knudsen for helpful reviews.

\section{References}

Abdeldayem, A. L., Paleomagnetism of some Cenozoic sediments, CairoFayum area, Egypt, Phys. Earth Planet. Inter., 110, 71-82, 1999.

Abdeldayem, A. L. and D. H. Tarling, Palaeomagnetism of some Tertiary sedimentary rocks, southwest Sinai, Egypt, in the tectonic framework of the S.E. Mediterranean, in Palaeomagnetism and Tectonics of the Mediterranean Region, edited by Morris, A. and Tarling, D. H., Geol. Soceity Special Publ. (London), 105, 333-343, 1996.

Abdel Monem, A. A. and M. A. Heikal, Major element composition, magma type and tectonic environmrnt of Mesozoic to Recent basalt, Egypt: a review, Fac. Earth Sci. Bull., King Abdul Aziz Univ., 4, 121148,1981

Andrew, G., The late Tertiary igneous rocks of Egypt (field relations), Bull. Fac. Sci. Egypt. Cairo Univ., 10, 1-44, 1937.

Ball, J., The Geography and Geology of West Central Sinai, Egypt, Survey Department, Cairo, 1916.

Beadnell, H. J. L., The topography and geology of the Fayum Province of Egypt, Egypt. Survey Dept., Cairo, 101 pp., 1905.

Besse, J. and V. Courtillot, Apparent and true polar wander and the geometry of the geomagnetic field over the last $200 \mathrm{Myr}$, J. Geophys. Res., 107, doi:10.1029/2000JB000050, 2002.

Beyth, M., Paleozoic vertical movements in Um Bogma area, southwestern Sinai, Bull. Am. Assoc. Petrol. Geol., 65, 160-165, 1981.

Coe, R. S., Paleo-Intensities of the Earth's Magnetic Field Determined from Tertiary and Quaternary rocks, J. Geophys. Res., 72, 3247-3262, 1967.

Day, R., M. D. Fuller, and V. A. Schmidt, Hysteresis properties of titanomagnetites: Grain size and composition dependence, Phys. Earth Planet. Inter., 13, 260-266, 1977.

Druckman, Y., T. Weissbrod, and A. Horowitz, The Budra formation: a Triassic continental deposit in southwestern Sinai, Report Geol. Surv. Israel, $\mathrm{N}^{\circ} \mathrm{OD} / 3 / 70,20$ pp., 1970.

El-Hinnawi, E. E., Petrochemical and geochemical studies on Egyptian basalts, Bull. Volcan., 28, 1-12, 1965.

El-Hinnawi, E. and M. Abdel Maksoud, Petrography of Cenozoic volcanic rocks of Egypt, Geol. Rdsch., 57, Stuttgart, 1968. 
El-Hinnawi, E. and M. Abdel Maksoud, Geochemistry of Egyptian Cenozoic basaltic rocks, Chimie der Erde, 31, 93-112, 1972.

Harrell, J. A. and T. M. Bown, An old Kingdom basalt Quarry at Widdan el-Faras and the Quarry Road to Lake Moeris, J. Amer. Res. Center Egypt, 71-90, 1995.

Heikal, M. A., M. A. Hassan, and Y. A. El-Sheshtawy, Cenozoic basalt of Gabal Qatrani, Western Desert, Egypt, as an example of continental tholeiitic basalt, Ann. Geol. Surv. Egypt, Cairo, Egypt, 13, 193-209, 1983.

Hume, W. F., T. G. Madgwick, F. W. Monn, and H. Sadek, Preliminary geological report of the occurrences of petroleum, in western Sinai, Petrol. Res. Bull. 2, Government Press, Cairo, 1920.

Hussain, A. G., H. Soffel, and A. Schult, Paleomagnetism of the Qatrani basalts, western desert, Egypt, Acad.Sc. Res. Techno., Helwan Observ., 224, 1-9, 1980.

Ibrahim, E., H. Odah, N. El-Agami, and M. Abu El-Enen, Paleomagnetic and geologic investigations on some volcanic rocks, southern Sinai, Egypt, Egyptian J. Geol., 42(1), 79-98, 1998.

Ibrahim, E. H., H. H. Odah, N. L. El Agami, and M. Abu El Enen, Paleomagnetic and geological investigation into Southern Sinai volcanic rocks and the rifting of the Gulf of Suez, Tectonophys., 321, 343-358, 2000 .

Issawi, B. and U. Jux, Contribution to the stratigraphy of the Paleozoic rocks in Egypt, Geol. Surv. Egypt, paper 64, 28 pp., 1982.

Kirschvink, J., The least squares line and plane and analysis of Paleomagnetic data, Geophys. J. Astr. Soc., 62, 699-718, 1980.

Kora, M., Lower Carboniferous calcareous microfossils from the Gulf of Suez region, Egypt. Geol. Palaeontol., 29, 217-231, 1995.

Kostandi, A. B., Lower Carboniferous calcareous microfossils from the Gulf of Suez region, Egypt. Geol. Palaeontol., 29, 217-231, 1959.

Lofty, H. I., Structural and geotectonic implications induced from paleomagnetic studies of some Phanerozoic basaltic eruptions, Ph.D. thesis, El-Minia Univ., 1992.

Lofty, H. I., R. Van Der Voo, C. M. Hall, O. A. Kamel, and A. Y. Abdel Aal, Paleomagnetism of early Miocene basaltic eruptions in the areas East and West of Cairo, J. Afric. Earth Sci., 21(3), 407-419, 1995.
McFadden, P. L., R. T. Merrill, M. W. McElhinny, and L. Sunhee, Reversals of the Earth's magnetic field and temporal variations of the dynamo families, J. Geophys. Res., 96, 3923-3933, 1991.

Meneisy, M. Y. and H. Kreuzer, Potassium-Argon ages of Egyptian basaltic rock, Geol. Jahrb., D9, 21-31, 1974.

Meneisy, M. Y. and A. Y. Abdel-Aal, Geochronology of Phanerozoic volcanic activity, Egypt. Bull. Fac. Sci., Ain Shams Univ., Cairo, Egypt, 24, 163-176, 1984.

Mousa, H. E., Geologic studies and genetic correlation of basaltic rocks in West Central Sinai, Ph.D thesis, Fac. Sci., Ain Shams University, 1987.

Perrin, M., Paleointensity determination, magnetic domain structure, and selection criteria, J. Geophys. Res., 103(B12), 30591-30600, 1998.

Poidras, T., P. Camps, and P. Nicol, Controlled atmosphere vibrating thermo-magnetometer $\left(\mathrm{C}_{\mathrm{at}} \mathrm{VTM}\right)$ : a new device to optimize the absolute paleointensity determinations, Earth Planets Space, 61, this issue, 101-110, 2009.

Said, R., The Geology of Egypt, 377 pp., Elsevier, Amsterdam, 1962.

Said, R., The Geology of Egypt, 734 pp., Balkema, Rotterdam, Brookfield, 1990.

Saleh, A., S. Saleh, and A. Schult, Paleomagnetism and rock magnetism of early Miocene basaltic rocks from West Central Sinai Peninsula, Egypt J. Appl. Geophys., 3(2), 51-60, 2004.

Steen, G., Radiometric age dating and tectonic significance of some Gulf of Suez igneous rocks, 6th Petrol. Explor. Seminar, EGPC, Cairo, 1982.

Thellier, E. and O. Thellier, Sur L'intensité du champ magnétique terrestre dans le passé historique et géologique, Ann. Géophys., 15, 285-376, 1959.

Wassif, N. A., Data concerning the magnetic, palaeomagnetic and mineralogical properties of some basalts from Wadi Matulla and Wadi Budra, Sinai, Egypt, Ain Shoms Sci. Bull., 27, 13-35, 1989.

Wassif, N. A., Paleomagnetism and opaque mineral oxides of some basalt from west central Sinai, Geophys. J. Int., 104, 319-330, 1991.

M. Perrin (e-mail: Mireille.Perrin@gm.univ-montp2.fr), A. Saleh, and L. Alva-Valdivia 